tumoral thymidylate synthase and p53 in metastatic colorectal cancer patients receiving fluorouracil-based chemotherapy: phenotypic and genotypic analyses. J Clin Oncol 20: 2832-2843

Fallik D, Borrini F, Boige V, Viguier J, Jacob S, Miquel C, Sabourin JC, Ducreux M, Praz F (2003) Microsatellite instability is a predictive factor of tumor response to irinotecan in patients with advanced colorectal cancer. Cancer Res 63: 5738-5744

Kim K, Nam E, Lee NS, Lee HR, Lee JY, Lee HR, Park SH, Oh SY, Kim JH, Song SY, Park JO, Kim WS, Jung CW, Im YH, Lee MH, Lee WY, Chun H, Park CH, Park K, Kang WK (2002) Oxaliplatin and UFT combination chemotherapy in patients with metastatic colorectal cancer. Am J Clin Oncol 25: $354-357$

Mabro M, Artru P, Flesch M, Maindrault-Goebel F, André T, Lledo G, Landi B, Aparicio T, Colin P, de Gramont A (2003) Irinotecan, 5-fluorouracil infusion and leucovorin (FOLFIRI-3) in pretreated patients with metastatic colorectal cancer: results of a multicenter phase II study. Proc Am Soc Clin Oncol 22: 280 (abstract 1125)

Mackay HJ, Hill M, Twelves C, Glasspool R, Price T, Campbell S, Massey A, Macham MA, Uzzel M, Bailey SM, Martin C, Cunningham D (2003) A phase I/II study of oral uracil/tegafur (UFT), leucovorin and irinotecan in patients with advanced colorectal cancer. Ann Oncol 14: $1264-1269$
Maindrault-Goebel F, de Gramont A, Louvet C, André T, Carola E, Mabro M, Artru P, Gilles V, Lotz JP, Izrael V, Krulik M (2001) High-dose intensity oxaliplatin added to the simplified bimonthly leucovorin and 5fluorouracil regimen as second-line therapy for metastatic colorectal cancer (FOLFOX 7). Eur J Cancer 37: 1000-1005

Mariadason JM, Arango D, Shi Q, Wilson AJ, Corner GA, Nicholas C, Aranes MJ, Lesser M, Schwartz EL, Augenlicht LH (2003) Gene expression profiling-based prediction of response of colon carcinoma cells to 5-fluorouracil and camptothecin. Cancer Res 63: 8791-8812

Mineo TC, Ambrogi V, Tononi G, Bollero P, Roselli M, Mineo D, Nofroni I (2003) Longterm results after resection of simultaneous and sequential lung and liver metastases from colorectal carcinoma. J Am Coll Surg 197: $386-391$

Petrioli R, Sabatino M, Fiaschi AI, Marsili S, Pozzessere D, Messinese S, Correale P, Civitelli S, Tanzini G, Tani F, De Martino A, Marzocca G, Lorenzi M, Giorgi G, Francini G (2004) UFT/leucovorin and oxaliplatin alternated with UFT/leucovorin and irinotecan in metastatic colorectal cancer. Br J Cancer 90: 306-309

Saltz L, Cox JV, Blanke C, Rosen LS, Fehrenbacher L, Moore MJ, Maroun JA, Ackland SP, Locker PK, Pirotta N, Elfring GL, Miller LL (2000) Irinotecan plus fluorouracil and leucovorin for metastatic colorectal cancer. $N$ Engl J Med 343: $905-914$

\title{
Reply: UFT/leucovorin and oxaliplatin alternated with UFT/ leucovorin and irinotecan in metastatic colorectal cancer
}

\author{
G Francini*,I and R Petrioli' \\ 'Department of Human Pathology and Oncology; Medical Oncology section, University of Siena, Viale Bracci II, 53 I 00 Siena, Italy
}

British Journal of Cancer (2004) 91, 600-602. doi: I0.1038/sj.bjc.66020I7 www.bjcancer.com

Published online 6 July 2004

(c) 2004 Cancer Research UK

Sir,

We would like to thank Dr Alliot for his comments concerning our study of metastatic colorectal cancer patients treated with $\mathrm{UFT} / \mathrm{LV}+\mathrm{L}-\mathrm{HOP}$ alternated with UFT/LV + CPT-11 (Petrioli et al, 2004).

In relation to the baseline characteristics of the enrolled patients, it was pointed out in the Discussion that 'the performance status and the percentage of chemonaive patients suggested a better than average group with regard to efficacy and toxicity'. As far as metastatic sites are concerned, a selection bias is common to small phase II studies. It is also worth pointing out that most of the metastatic colorectal cancer patients enrolled in clinical trials have $\leqslant 2$ metastatic sites (as in our study population). Furthermore, patients undergoing surgery for colorectal cancer are unlikely to have metastatic sites other than the liver, lung and peritoneum, and those having three or more metastatic sites are unlikely to have a performance status that would allow their enrolment in a chemotherapeutic protocol. Finally, phase II studies do not usually report baseline CEA, albumin and LDH levels because these have little prognostic value in the case of patients

*Correspondence: Professor G Francini; E-mail: francini@unisi.it

Published online 6 July 2004 with advanced disease (Douillard et al, 2000; Saltz et al, 2000; Souglakos et al, 2002; Zeuli et al, 2003).

In relation to the low level of toxicity, it should be remembered that this was also due to the advantage of oral chemotherapy: that is, unlike boluses and continuous infusions, the treatment can be discontinued when toxicity arises and before it worsens (Twelves and Cassidy, 2002).

About $20 \%$ of our patients underwent postchemotherapy surgery for residual metastases, thus confirming the efficacy of the proposed chemotherapy protocol. However, postchemotherapy surgery led to a major advantage in terms of global survival in very few cases $(9 \%)$.

The fact that $85 \%$ of our patients underwent primary tumour surgery is said to be a major recruitment bias, but we would like to point out that this percentage is the same or lower than that reported in the majority of studies of metastatic colorectal cancer (Van Cutsem et al, 2001; Twelves et al, 2001; Schilsky et al, 2002; Falcone et al, 2002).

As mentioned in the Discussion, low dose intensities of L-HOP and CPT-11 can be expected when using an alternating chemotherapy regimen. Nevertheless, the results of the study are supported by other studies of alternating chemotherapy in patients with metastatic colorectal cancer, suggesting that prolonged tumour exposure to a fluoropyrimidine plus full doses of L-HOP 
alternated with full doses of CPT-11 can be effective and well tolerated (Van Cutsem et al, 1998; Reina et al, 2003; Aparicio et al, 2003). Furthermore, it needs to be remembered that an aggressive chemotherapeutic approach can lead to numerous dose adjustments and delays, which inevitably lower the planned dose intensities, and it is difficult to continue the treatment over time (Falcone et al, 2002; Souglakos et al, 2002; Ychou et al, 2003).

Concerning the possibility of using higher doses of UFT, we would like to point out that we chose a fixed dose of $250 \mathrm{mg} \mathrm{m}^{-2}$ day $^{-1}$ for 28 days on the basis of the activity and tolerability of UFT/LV + L-HOP or UFT/LV + CPT-11 demonstrated by previous phase I/II studies (Price and Hill, 2000; Vanhoefer and Wilke, 2001). The risk of overlapping diarrhoea is certainly greater with the combination of UFT/LV and CPT-11, and so higher UFT doses could perhaps be used in combination with LHOP. However, other studies are difficult to interpret in this sense because they used shorter UFT administration schedules (21 days), which reduce the risk of diarrhoea (Kim et al, 2002; MacKay et al, 2003).

We believe that the hypothesis that more patients might have benefited from heavier regimens is difficult to support. Although $54 \%$ of the patients were candidates for a second surgical intervention, the albeit low $7.3 \%$ rate of complete remission (CR), which is considered the main indicator of treatment efficacy, was similar to that observed with much more aggressive chemotherapy regimens in patients with similar characteristics to those of our study population (Buyse et al, 2000; Saltz et al, 2000; Falcone et al, 2002; Souglakos et al, 2002). This suggests that the CR rate is more related to the biological characteristics of the tumour than the chemotherapy dose. We have obtained similar CR rates in previous clinical trials using the simple schedule of folinic acid and 5fluorouracil (Francini et al, 1988; Petrioli et al, 1995).
In relation to the possible selection of resistant clones, the rationale of an alternating schedule is to ensure that full doses of all active agents can be administered by avoiding the potential incidence of overlapping side effects that may occur with concomitant drug administration. Our results suggest that a treatment based on low dose intensities of the more active drugs can be administered for a long time with a high level of tolerability, and similar response, time to progression and survival rates to those observed using more aggressive chemotherapy regimens (Douillard et al, 2000; Saltz et al, 2000; Souglakos et al, 2002).

Dr Alliot also raises the question of second-line chemotherapy, but this is a known problem when more active drugs are used. Furthermore, the results of second-line chemotherapies are generally unsatisfactory, whereas the simultaneous use of all of the drugs active in first-line treatment is an attempt to improve prognosis and many studies are investigating this approach (Falcone et al, 2002; Ychou et al, 2003).

Finally, we agree that, in a subgroup of patients with initially unresectable metastatic colorectal cancer, active first-line chemotherapy may permit secondary radical surgery of metastases, and this was also possible in our study population (Bismuth et al, 1996). Furthermore, neoadjuvant treatments play an important role in all types of neoplasms. However, the aim of our study was not to develop a neoadjuvant treatment but a new chemotherapy regimen that could improve patient compliance and reduce side effects. In the absence of phase I data concerning the recommended dose of a three-drug combination, we chose to alternate the previously explored combinations of UFT/LV + CPT-11 and UFT/LV + L-HOP and, albeit with all of the limitations of a small phase II study, the results seemed to be interesting because of the association of efficacy and little toxicity.

\section{REFERENCES}

Aparicio J, Fernandez-Martos C, Vicent JM, Maestu I, Llorca C, Campos JM, Busquier I, Calderero V (2003) Biweekly alternating FOLFOX and FOLFIRI in patients with previously untreated, advanced colorectal cancer (ACC). Preliminary results. Proc Am Soc Clin Oncol 22: 334 (abstrct 1341). 1341

Bismuth H, Adam R, Levi F, Farabos C, Waechter F, Castaing D, Majno P, Engerran L (1996) Resection of nonresectable liver metastases from colorectal cancer after neoadjuvant chemotherapy. Ann Surg 224: $509-522$

Buyse M, Thirion P, Carlson RW, Burzykowski T, Molenberghs G, Piedbois P (2000) Relation between tumour response to first-line chemotherapy and survival in advanced colorectal cancer: a meta-analysis. Meta-Analysis Group in Cancer. Lancet 356: 373-378

Douillard JY, Cunningham D, Roth AD, Navarro M, James RD, Karasek P, Jandik P, Iveson T, Carmichael J, Alakl M, Gruia G, Award L, Rouigier P (2000) Irinotecan combined with fluorouracil compared with fluorouracil alone as first-line treatment for metastatic colorectal cancer: a multicenter randomised trial. Lancet 355: $1041-1047$

Falcone A, Masi G, Allegrini G, Danesi R, Pfanner E, Brunetti IM, Di Paolo A, Cupini S, Del Tacca M, Conte P (2002) Biweekly chemotherapy with oxaliplatin, irinotecan, infusional fluorouracil, and leucovorin: a pilot study in patients with metastatic colorectal cancer. J Clin Oncol 20: 4006-4014

Francini G, Setacci C, Lorenzi M, Petrioli R, Paffetti P, Gennari C, Armenio S, Lorenzini L (1988) Treatment of advanced colorectal cancer with a combination of 5-fluorouracil and folate. Tumour markers monitoring. XXVI World Congress of the International College of Surgeons, Milan, Monduzzi Editore V. 379-382

Kim K, Nam E, Lee NS, Lee HR, Lee JY, Lee HR, Park SH, Oh SY, Kim JH, Song SY, Park JO, Kim WS, Jung CW, Im YH, Lee MH, Le WY, Chun H, Park CH, Park K, Kang WK (2002) Oxaliplatin and UFT combination chemotherapy in patients with metastatic colorectal cancer. Am J Clin Oncol 25: $354-357$
Mackay HJ, Hill M, Twelves C, Glasspool R, Price T, Campbell S, Massey A, Macham MA, Uzzel M, Bailey SM, Martin C, Cunningham D (2003) A phase I/II study of oral uracil/tegafur (UFT), leucovorin and irinotecan in patients with advanced colorectal cancer. Ann Oncol 14: $1264-1269$

Petrioli R, Lorenzi M, Aquino A, Marsili S, Frediani B, Palazzuoli V, Marzocca G, Botta G, Tani F, De Martino A, Testi W, Setacci C, Salvestrini F, De Sando D, Bovenga S, Mariani L, Tanzini G, Armenio S, Marinello E, Francini G (1995) Treatment of advanced colorectal cancer with high-dose intensity folinic acid and 5-fluorouracil plus supportive care. Eur J Cancer 31A: 2105-2108

Petrioli R, Sabatino M, Fiaschi AI, Marsili S, Pozzessere D, Messinese S, Correale P, Civitelli S, Tanzini G, Tani F, De Martino A, Marzocca G, Lorenzi M, Giorgi G, Francini G (2004) UFT/leucovorin and oxaliplatin alternated with UFT/leucovorin and irinotecan in metastatic colorectal cancer. Br J Cancer 26: 306-309

Price T, Hill M (2000) UFT/leucovorin plus irinotecan in advanced or metastatic colorectal cancer. Oncology 14(Suppl 9): 28-31

Reina JJ, Aparicio J, Salvador J, Pica JM, Rueda A, Lorenzo A, de la Puente CG, Borrega P, Moreno-Nogueira JA (2003) A multicenter phase II study of irinotecan (CPT-11) alternated with 5-fluorouracil and leucovorin as first-line treatment of patients with metastatic colorectal cancer. Cancer Chemother Pharmacol 52: 339-345

Saltz LB, Cox JV, Blanke C, Rosen LS, Fehrenbacher L, Moore MJ, Maroun JA, Ackland SP, Locker PK, Pirotta N, Elfring GL, Miller LL (2000) Irinotecan plus fluorouracil and leucovorin for metastatic colorectal cancer. $N$ Engl J Med 343: $905-914$

Schilsky RL, Levin J, West WH, Wong A, Colwell B, Thirlwell MP, Ansari RH, Bell WN, White RL, Yates BB, McGuirt PV, Pazdur R (2002) Randomized, open-label, phase III study of a 28-day oral regimen of eniluracil plus fluorouracil versus intravenous fluorouracil plus leucovorin as first-line therapy in patients with metastatic/advanced colorectal cancer. J Clin Oncol 20: $1519-1526$ 
Souglakos J, Mavroudis D, Kakolyris S, Kourousis Ch, Vardakis N, Androulakis N, Agelaki S, Kalbakis K, Tsetis D, Athanasiadis N, Samonis G, Georgoulias V (2002) Triplet combination with irinotecan plus oxaliplatin plus continuous-infusion fluorouracil and leucovorin as first-line treatment in metastatic colorectal cancer: a multicenter phase II trial. J Clin Oncol 20: 2651 - 2657

Twelves C, Boyer M, Findlay M, Cassidy J, Weitzel C, Barker C, Osterwalder B, Jamieson C, Hieke K, on behalf of the Xeloda Colorectal Cancer Study Group (2001) Capecitabine (Xeloda TM) improves medical resource use compared with 5-fluorouracil plus leucovorin in a phase III trial conducted in patients with advanced colorectal carcinoma. Eur J Cancer 37: $597-604$

Twelves CJ, Cassidy J (2002) Which endpoints should be used in evaluating the use of novel fluoropyrimidine regimens in colorectal cancer? $\mathrm{Br}$ Cancer 86: $1670-1676$

Van Cutsem E, Pozzo C, Starkhammar H, Dirix L, Terzoli E, Cognetti F, Humblet Y, Garufi C, Filez L, Gruia G, Cote C, Barone C (1998) A phase II study of irinotecan alternated with five days bolus of 5-fluorouracil and leucovorin in first-line chemotherapy of metastatic colorectal cancer. Ann Oncol 9: 1199-1204
Van Cutsem E, Twelves C, Cassidy J, Allman D, Bajetta E, Boyer M, Bugat R, Findlay M, Frings S, Jahn M, McKendrick J, Osterwalder B, Perez-Manga G, Rosso R, Rougier P, Schmiegel WH, Seitz JF, Thompson P, Vieitez JM, Weitzel C, Harper P, Xeloda Colorectal Cancer Study Group (2001) Oral capecitabine compared with intravenous fluorouracil in patients with metastatic colorectal cancer: results of a large phase III study. J Clin Oncol 19: 40974106

Vanhoefer U, Wilke H (2001) Oral fluoropyrimidine-based combination therapy in gastrointestinal cancer. Oncology 15(Suppl 2): $79-84$

Ychou M, Conroy T, Seitz JF, Gourgou S, Hua A, Mery-Mignard D, Kramar A (2003) An open phase I study assessing the feasibility of the triple combination: oxaliplatin plus irinotecan plus leucovorin/5-fluorouracil every 2 weeks in patients with advanced solid tumors. Ann Oncol 14: $481-489$

Zeuli M, Nardoni C, Pino MS, Gamucci T, Gabriele A, Ferraresi V, Giannarelli D, Cognetti F (2003) Phase II study of capecitabine and oxaliplatin as first-line treatment in advanced colorectal cancer. Ann Oncol 14: $1378-1382$ 